PF 2020 (75/1): 11-32

https://doi.org/10.32798/pf.645

\author{
ANA ADAMOVIČOVÁ \\ Ústav bohemistických studií \\ Filozofická fakulta, Univerzita Karlova, Praha \\ e-mail: ana.adamovicova@ff.cuni.cz \\ ORCID 0000-0003-4074-156X
}

\title{
VALENCE PARTIKULÍ NA ZÁKLADĚ DAT Z PRAŽSKÉHO MLUVENÉHO KORPUSU
}

\section{VALENCY OF PARTICLES BASED ON PRAGUE SPOKEN CORPUS}

\begin{abstract}
The article deals with valency properties of particles in common spoken Czech. It is based on the material from the Prague Spoken Corpus (PSC), the first Czech spoken corpus. After a brief introduction of the input corpus material and the main results of the survey, it focuses on the description of the valency of particles, i.e. their ability to bind to other words in a sentence, or to a sentence as a whole, which is closely related to their place in the sentence order. Further focus is on the accumulation of particles within a sentence: from the syntactic point of view, it may be mainly textual, capturing only randomly repeating textual combinations of two or more particles next to each other, or systemic, which results in multiword particles. However, both kinds of processes point to combinatorial possibilities of particles. Finally, the immediate surroundings of all particles that occur in PSC is presented.
\end{abstract}

KEYWORDS: collocability, accumulation of particles, syntagmatic relations, multi-word items

KLÍČOVÁ SLOVA: kolokabilita, kumulace partikulí, syntagmatika, víceslovné jednotky SŁOWA KLUCZOWE: kolokabilność, kumulacja partykuł, syntagmatyka, jednostki wielowyrazowe

\section{1. Úvod}

Definic valence najdeme v lingvistické literatuře povícero. Poměrně výstižná se nám zdá ta, kterou uvádí F. Čermák (1997, s. 182): „valence je systémový 
syntagmatický (ve slovníku potenciální) vztah slova ke slovům za i před ním, jejichž interpretaci a formu predeterminuje, často i pomocí morfologického či lexikálního signálu". Ačkoli se valenční vztahy zkoumají hlavně u autosémantických slovních druhů - verb, substantiv a adjektiv, budeme-li usilovat o hlubší popis, a to nejen mluveného jazyka, neměli bychom opomíjet ani průzkum valence partikulí, jemuž doposud nebyla věnována téměř žádná pozornost. Souvisí to zřejmě i s dlouho přetrvávajícím přehlížením jejich funkce při strukturování jazykového projevu, neméně i s dosti nejednotným a vágním př́stupem lingvistů $\mathrm{k}$ tomuto dlouho opomíjenému slovnímu druhu. Systematičtějšímu zpracování partikulí v češtině se od 80 . let minulého století věnovali hlavně $\mathrm{M}$. Grepl, O. Uličný a M. Nekula. Nutno však říct, že se jejich dosti propracované teorie málo opírají o skutečná data a rozsáhlou kontextovou analýzu. Partikule jsou přitom velmi frekventovaným slovním druhem a představují nedílnou součást každého běžného jazykového projevu.

O partikulích se již tradičně tvrdí, že nejsou syntaktickým členem ve výpově$\mathrm{di}^{1}$, většinou nenesou větný př́ízvuk ${ }^{2}$, jsou tedy vypustitelné, aniž se naruší smysl sdělení. Na druhou stranu, představíme-li si naši komunikaci bez partikulí, výsledkem bude černo-bílý strohý obraz bez všech jemných odstínů zrcadlících stav mysli, náladu, vnitřní postoj mluvčího, jeho ne/zaujatost tématem, ochotu a připravenost něco sdělit. Obecně vzato by se dalo říct, že partikule má, na rozdíl na prŕklad od adverbia, především komunikační (pragmatický) význam a je specifickým „kořením“ jazyka.

Průzkum partikulí je zde omezen na jejich výskyt v Pražském mluveném korpuse (PMK), který stručně představíme v dalším oddílu (1.1), jakožto i přístup uplatněný při jejich identifikaci a následné analýze (1.2). Další části článku $(2,3)$ se zaměří na popis valence partikulí realizované prímo v promluvě. $\mathrm{Na}$ tu bychom podle mého soudu měli nazírat jinak než v př́padě autosémantických slovních druhů. Zde totiž vyvstává otázka, již lze považovat za otevřenou: do jaké míry je valenční potenciál částic zastoupen př́mo v jazyce (langue), a do jaké míry je spíš výsledkem realizace $\mathrm{v}$ textu/promluvě (parole). V článku se tedy při použití autentických příkladů $\mathrm{z}$ kontextu zaměříme především na syntagmatiku a kolokabilitu částic, na jejich místo výskytu v promluvě a na jejich bezprostřední okolí. Jelikož se partikule, na rozdíl od interjekcí či frazémů, vždy těsně pojí s dalšími slovy či větou, o určitých vyšších či nižších preferencích takovýchto spojení jistě lze uvažovat.

1 Např̀. i v Novém encyklopedickém slovníku češtiny (Karlík et al. 2017) heslo o částicích začíná: „(...) synsémantická, neohebná funkční slova bez větněčlenské platnosti (...)“.

2 V materiálu Pražského mluveného korpusu však většina intenzifikačních a expresivních partikulí ve větě př́ízuk má: např. fakt si myslím, stejně je to hlupák, on si tu klidně spí apod. 


\subsection{Pražský mluvený korpus a výsledky analýzy dat}

PMK je první referenční mluvený korpus češtiny o rozsahu tři čtvrtě milionu jednotek. Nahrávky zachycující autentický mluvený projev vznikaly v letech 1988-1996. Výzkumů se zúčastnilo 504 respondentů vybraných podle čtyř sociolingvistických parametrů: pohlaví, věku (spodní hranice 18 let) a vzdělání. Čtvrtým parametrem je typ promluvy, tj. monolog zachycující odpovědi na předem stanovená témata týkající se každodenního života (názory na rodinu, vzdělání, mezilidské vztahy, pracovní prostředí, úspěšný a štastný život apod.), a dialog, tj. neřízený rozhovor dvou respondentů, kteří se znají, na jakékoli téma. Po věrném přepisu a ruční anotaci 15015 promluv, tj. cca 150 hodin mluveného projevu (omezeném ovšem na Prahu a její okolí) na základě Kódovníku $\mathrm{PMK}^{3}$ byly v roce 2007 zveřejněny první výsledky, jež se staly podkladem pro Frekvenční slovník mluvené češtiny (Čermák et al. 2007 - FSMČ).

PMK nám poskytl řadu zajímavých a daty podložených poznatků z hlediska jazykových prostředků podílejících se na uspořádání běžně mluveného projevu:

- partikule jsou třetím nejfrekventovanějším slovním druhem v mluveném jazyce $(13,51 \%)$ po slovesech $(17,89 \%)$ a zájmenech $(16,59 \%)$, čili v průměru každé sedmé použité slovo v mluveném projevu je partikulíi ;

- mezi 100 nejfrekventovanějšími slovy v PMK je pouze třetina autosémantických, dvě třetiny připadají na synsémantická slova - zájmena, partikule, spojky a prepozice;

- $\quad \mathrm{z}$ autosémantik se mezi první stovkou nejfrekventovanějších slov nejméně vyskytují adjektiva - pouze dvě, a to až na samém konci seznamu (93. dobrej a 96. jinej). Dalo by se říct, že hodnotící funkci adjektiv v mluveném jazyce přebírají partikule a kvalifikující propoziční frazémy, např. To je šílený;

- na vysoké frekvenci tvarů partikulí se podílí poměrně malý počet lemmat: v PMK se vyskytlo 400 lemmat partikulí5 ( $\mathrm{v}$ češtině je ve skutečnosti kolem 450 lemmat partikulí6);

3 Kódovník PMK sestavil František Čermák pro účely ruční anotace celého korpusu. Při jeho tvorbě byly využity základní publikace zpracovávající českou morfologii a syntax (SSČ, AMČ 1-3), jakož i některé další domácí i zahraniční práce zabývající se obecně morfologií, frazeologií, syntagmatikou, kolokabilitou a valencí (morfologie: Bauer 1988; Matthews 1991; další: Čermák et. al. 2009 - SČFI; Čermák 1990; Čermák, Holub 2005).

4 Pro úplnost uvádíme frekvenční pořadí všech slovních druhů, frazémů a proprií, jejichž frekvenci jsme též sledovali, v PMK v procentech: 4. substantiva (13,33), 5. spojky $(10,94), 6$. adverbia $(8,47), 7$. prepozice $(6,39), 8$. adjektiva $(5,21), 9$. frazémy $(3,56), 10$. citoslovce $(1,48), 11$. číslovky $(1,42)$ a 12. propria $(1,09)$.

Srovnatelný počet lemmat jako partikule měly v PMK číslovky (480) a interjekce (339), zatímco výrazně méně lemmat měly spojky (267), zájmena (249), prepozice (199), citátové výrazy - např. de facto (168) a zkratky - např. FAMU (88).

6 Cca dalších 50 partikulí se v PMK bud' nevyskytlo (jedná se o zastaralá či př́liš knižní slova, např. též, žel, lautr), anebo při revizi materiálu bylo zjištěno, že některá homonymní slova 
- jen 20 \% lemmat partikulí má však v PMK frekvenci vyšší než 100 výskytů; až polovina lemmat partikulí má tedy i zde, v mluveném jazyce, velmi nízkou frekvenci;

- prvními 20 nejfrekventovanějšími lemmaty partikulí v PMK je: no, jako, tak, teda, prostě, třeba, a, že jo, asi, jo, taky, to, i, ale, vlastně, zase, no tak, $u \check{z}$, eště, vưbec - (poslední slovo má kolem 1000 výskytů);

- téměř polovina lemmat partikulí (48\%) je homonymní s dalšími slovními druhy - nejvíce homonymních lemmat je s adverbii (46\%);

- homonymie tvarů v kontextu promluvy je však ještě vyšší (64 \%), z čehož je opět nejvíce partikulí homonymních s adverbii (36 \%) a přibližně stejně se spojkami (27\%) a citoslovci (26\%).

\subsection{Identifikace partikulí a jejich hlavní funkce $v$ kontextu}

Materiál PMK a jeho následné zpracování, tj. rozsáhlá ruční anotace ${ }^{7}$ nám poskytl jedinečnou možnost popsat funkce a význam partikulí v bezprostředním autentickém kontextu a v úzu, tj. tam, kde se přirozeně vyskytují. Kontext užití je rozhodujícím kritériem pro jejich identifikaci a umožňuje jednak osvětlit kontextovou podmíněnost vzniku nové funkce řady homonymních výrazů, jednak ilustrovat procesy partikulizace četnými autentickými př́íklady.

V př́padě zkoumání partikulí jde o zcela klíčový přístup: vzhledem k vysokému procentu homonymních tvarů řady partikulí s dalšími slovními druhy je jejich automatická identifikace dosti nepřesná a zavádějící. Analýza rozsáhlých kontextů, v nichž partikule často vznikají změnou funkce ve výpovědi, umožňuje zachytit je $\mathrm{v}$ jejich přirozeném okolí.

Pražský mluvený korpus je tedy první český korpus, který nabízí plné, systematické a pečlivě ověřované tagování všech svých forem, kde se u každého slovního druhu hlouběji rozlišuje až desítka dalších kategorií. V případě partikulí Kódovník PMK počítá s 6 pozicemi (viz Příloha).

Připomeňme si nyní nejčastější funkce partikulí v promluvě, které jsou doloženy v materiálu PMK. Obecně lze říct, že až na výjimky jde o jakýsi pragmatický komentár různého typu:

- většina funkcí je těsně spjatá s vyjádřením postoje mluvčího vůči obsahu sdělení či partnerovi v promluvě;

byla v PMK anotována pouze jako adverbium (např. zdaleka; ve větě přišel zdaleka jde o adverbium, avšak ve větě to $z$ daleka není všechno jde o partikuli).

Pokud je nám známo, od doby vzniku PMK nebyl žádný další korpus ručně označkován $\mathrm{v}$ takovém rozsahu a vzhledem k pracnosti manuálního značkování pravděpodobně už ani v takovém rozsahu označkován nebude. 
- dominantními funkcemi jsou funkce modální přes celou škálu funkcí faktuálních (např. asi, celkem, fakticky, jaksi, napríklad, prej, taky), intenzifikačních (nap̌r. absolutně, aspoň, hlavně, $i$, obzvlášt, vủbec, zrovna), expresivních (např. čistě, hezky, konečně, naprosto, pomalu, vono, zkrátka), emocionálních (např. bohužel, co dyž, eště, eště že, naštěstí, normálně, zaboha, zaplatpámbu) až po funkci čistě kontaktní (jo, že jo, vid);

- neméně důležitou je funkce referenční odkazující $\mathrm{k}$ různým úsekům promluvy (např. jinak, naopak, vlastně, zase);

- nelze nezmínit i nadužívání některých výrazů (populárně značených jako „berličky“ či slova výplňková, expletiva; vesměs jde o nejfrekventovanější slova, např. jako, teda, prostě).

Kontextová analýza též ukázala, že při běžně mluveném projevu mluvčí jakoukoli komunikační nejistotu vyvolanou hledáním lepšího formulačního obratu či snahou o lepší uchopení myšlenky často „maskuje“ partikulemi, které v těchto situacích používá ve vyšší míre, často i mimoděk. Nejfrekventovanější partikule lze označit za konvenční jazykové prostředky zaručující především plynulý tok promluvy ve všech fázích komunikace. V prrípadě funkčního posunu, při němž u homonymních slov dochází $\mathrm{k}$ nabývání nového významu v promluvě, lze mluvit i o jazykové kreativitě a vynalézavosti, jež proces partikulizace často doprovází. Data z PMK ukázala, že se řada původních adverbií mnohem častěji v kontextu promluvy užívá ve funkci partikule.

\section{Valence partikulí}

Díky pracné ruční anotaci celého korpusu, jež umožnila zjednoznačnění partikulí v kontextu promluvy, jsme získali cenný materiál. Už samotný fakt, že se na rozdíl od interjekcí či frazémů partikule vždy těsně váže ke slovu či $k$ větě a nikdy nestojí samostatně, nás vede ke snaze vystopovat jejich valenční preference. Tím především rozumíme jejich schopnost vázat se s dalšími slovy ve výpovědi, anebo s celou výpovědí, což těsně souvisí i s místem jejich výskytu.

V Kódovníku PMK (viz Př́loha) je valenci věnována 4. pozice. V kontextu promluvy se však partikule často vyskytují v různě dlouhém řetězení, a proto se $\mathrm{v}$ dalších částech článku nejprve podíváme na vnitřní syntagmatiku a kumulaci partikulí (2.1), dále na kombinace partikulí s větou, anebo se slovem (2.2) a v závěrečném oddílu (3) představíme bezprostř̌ední okolí všech partikulí, které se vyskytly v PMK. 


\subsection{Vnitřní syntagmatika partikulí: víceslovné partikule}

Kolokabilita je obecná schopnost slova pojit se $\mathrm{v}$ textu s jinými slovy. Tato spojitelnost nebo kombinovatelnost může probíhat $\mathrm{v}$ rámci celého paradigmatu či jeho jednotlivých členů s celými jinými paradigmaty či jejich členy. Kolokace (spojení slov) je původně pojem J. R. Firtha, který dál byl propracován M. Joosem (Filipec, Čermák 1985, s. 49, 57). Slova, jež spolu vytvářejí kolokace, vzájemně vykazují různé stupně kompatibility. Můžou spolu souviset jen gramaticky, pak mluvíme též o koligaci, anebo gramaticky i sémanticky, což je předpokladem pro široce pojaté trrídy kolokací. Pro kolokace je tedy příznačné, že je obtížné definovat je pouze sémanticky, protože se gramatická a lexikální rovina v nich přirozeně prolínají. Tuto spojitost zahrnuje valence slova, spojující v sobě předpoklady morfologické, ovšem také sémantické a syntaktické. Kolokace dále lze dělit na systémové (ustálené; např. jen aby), textové (vznikající ad hoc v textu / / promluvě; napřr. zrovna ten, právě ted), a případně kombinované, textově-systémové tvořící přechod mezi termínovými a běžnými kolokacemi (Čermák 2001, s. 228-229).

Systémové víceslovné partikule byly poprvé ručně označeny v materiálu PMK. Vůbec poprvé se tomuto gramaticko-lexikálnímu jevu soustavně věnoval F. Čermák ve 2. svazku Slovníku české idiomatiky a frazeologie pojmenovaném Výrazy neslovesné. Tento svazek obsahuje několik typů neslovesných frazémů, a to frazémy nominální zahrnující substantivní, adjektivní a zájmenné frazémy, dále frazémy adverbiální, a konečně také frazémy relační zahrnující prepozicionální, konjunkční, deiktické a partikulární frazémy. Relační frazémy, které nás zde budou zajímat nejvíce, mají za základ složené výrazy gramatické povahy, jejichž funkce ve výpovědi však odpovídá jednoslovným výrazům synsémantickým. Tyto výrazy různým způsobem modifikují řídící substantivum, verbum, popřípadě adjektivum či adverbium, anebo také celou výpověd'. Jen zčásti jde o výrazy čistě nocionální, většinou jejich význam či celkové vyznění má hodnotící anebo intenzifikační ráz. Z hlediska stylu je pro ně př́iznačná př́íznakovost a expresivita.

Víceslovných partikulí je mnohem méně než jednoslovných: poměr lemmat v PMK je zhruba $2 / 3$ jednoslovných $\mathrm{k} 1 / 3$ víceslovných, frekvence jejich tvarů je však mnohonásobně nižší, jak znázorňuje následující tabulka:

\begin{tabular}{|l|l|l|l|}
\hline \multicolumn{2}{|c|}{ Jednoslovné nehom. part. } & \multicolumn{2}{c|}{ Víceslovné nehom. part. } \\
\hline teda & 4678 & že jo & 2542 \\
\hline prostě & 3924 & no tak & 1144 \\
\hline asi & 2438 & přece jenom & 209 \\
\hline taky & 2257 & třeba i & 141 \\
\hline
\end{tabular}




\begin{tabular}{|l|l|l|l|}
\hline \multicolumn{2}{|c|}{ Jednoslovné nehom. part. } & \multicolumn{2}{c|}{ Víceslovné nehom. part. } \\
\hline vlasně & 1784 & nebo tak & 77 \\
\hline vůbec & 1068 & nebo co & 54 \\
\hline spíš & 615 & ne že ale & 41 \\
\hline vid’ & 478 & když už & 36 \\
\hline snad & 477 & jen tak & 35 \\
\hline hlavně & 388 & až tak & 28 \\
\hline
\end{tabular}

Tabulka 1. 10 nejfrekventovanějších jednoslovných a víceslovných vlastních (nehomonymních) partikulí v kontextu PMK

Nízká frekvence těchto výrazů může být způsobena i metodologickými nejasnostmi ohledně zařazení těchto slov, což na druhou stranu může být dáno velkou mírou jejich splývavosti s jinými slovními druhy, především frazémy či víceslovnými spojkami. $\mathrm{K}$ tomu, abychom jistou jednotku začali vnímat jako víceslovnou, musíme mít oporu v úzu. Tyto jednotky sice vznikají častým opakováním téže kombinace, pouhá kumulace jednoslovných výrazů však nemusí být dostatečným důvodem $\mathrm{k}$ tomu, abychom jí přiřadili statut víceslovnosti, respektive ustálenosti.

Řada víceslovných partikulí je homonymní s frazémy: zatímco frazém stojí samostatně (no a? to teda!), víceslovná partikule (at systémová, nebo textová) se vždy váže $\mathrm{k}$ určitému úseku věty či ke slovu ( $k d y z ̌$ to slyším, tak sem uplně $z$ toho nepríčetná ... no a já ríkám "právě prostě "pořád, což teda úplně to někdy nechápu; ...šstastný život bez psychickýho vyrovnání, no a to psychický vyrovnání, to spočivá zase rozhodně.../.../ i na tý ekonomický stránce...; já sem nemohla spát pres tu bouřku, to teda skutečně sem nespala). Po dlouhých debatách jsme např. velmi četnou kombinaci no $+a$ ze seznamu ustálených víceslovných partikulí vyřadili, ačkoli je její frekvence v PMK velmi vysoká (1187 výskytů). Shodli jsme se na tom, že je no a (co) v některých kontextech frazémem ve významu co má $b e j t$. Ve většině případů pouhá kombinace no_a měla pouze navazující funkci ve vyprávění a nejčastěji šlo o dvě partikule, anebo partikuli a spojku.

Víceslovné partikule představují otevřenou třídu, která se pozvolna rozrůstá: z náhodných textových kumulací vznikají systémové, ustálené - prvním předpokladem je jejich vysoká frekvence a časem i lexikalizace dané jednotky, která má svou jedinečnou sémantiku, pomocí níž mluvčí zaujímá jistý postoj (jen jestli - pochybnost, jen aby - obava a přání, už aby - přání, touha, ne aby - hrozba, co $k d y b y$ - návrh, přesvědčování, ještě že - úleva, co když - obava, no tak - váhavost, distancovanost, $k d y z ̌ u z ̌$ - dodatečné přitakání, rezignovanost apod.). Většina se vyskytuje bezprostředně vedle sebe, pojí se s větou v iniciálové pozici. Distanční 
pozice druhého komponentu zřejmě není tak častá, vyskytuje se hlavně u těchto výrazů: co-to, čím-tím, kudy-tudy, at'-co.

Pokud jde o kombinace, je zřejmé, že se většinou kombinují krátké spojky: $a, i$, $a b y, a n i, a t, d y z ̌, d y b y, j a k, n e b o, z ̌ e ~ a ~ p a r t i k u l e$, př́padně adverbia: eště, jen, možná, ňák, prece, spiš, takle, už. Nejméně častou kombinací je kombinace dvou partikulí, př́padně adverbia - prece jen(om) - jinak poměrně dosti frekventované víceslovné partikule. Je zajímavé, že některá slova (převážně jde o spojky a partikule - jedinou výjimkou je imperativ dejme) mohou stát jen na začátku spojení: $a-14$ krát jen první pozice, nebo 4krát, at', čim, ne 3krát, ani, přece, že 2krát, eště, hlavně, dejme, $n o, u \check{z}, k d y b y$ jednou, zatímco některá slova zase jen na konci spojení (zde se kromě spojek a partikulí vyskytují hlavně adverbia): aby, potom, přitom, takle, možná, jesli, spiš. Část výrazů může však stát jak na začátku, tak i na konci spojení, např. co:

co dyby, co dyž, co možná, co to vs. at' co, nebo co, podle toho co; dyž: dyž tak, dyž už $v s$. co dyž, kór dyž; jak: jak to že $v s$. at jak; jen: jen aby, jen tak $v s$. přece jen; jenom: jenom jesi, jenom tak $v$ s. přece jenom; kór: kór dyž $v s$. a kór; tak: tak at $v s$. dyž tak, ani ne tak, asi tak, až tak, i tak, jen tak, jenom tak, nebo tak; ňák: ňák tak vs. tak ňák ap.

Nejvyšší počet kombinací vykazují spojka $a$ a partikule /adverbium tak. Kromě kombinací dvou slov se méně často může ustálit i kombinace tří až čtyř slov, např. a když tak, ani ne tak ale.

Systémové víceslovné partikule bezesporu představují otevřenou tř́du a nejspíš můžeme očekávat nárůst různých kombinací. V podkapitole o kumulaci partikulí (viz 2.1.1) zmíníme i další kombinace, které je možné považovat za poloustálené a které se časem třeba ustálí, ačkoli původně při anotaci PMK nebyly označené jako víceslovné.

Jak už jsme poukázali, problémem při jejich určování je i značné splývání $\mathrm{s}$ frazeologií a občas i nejasná hranice v textu, resp. promluvě: vše, co je v těsném sepjetí s promluvou a je těsně zakomponováno do její struktury, by mělo být považováno za víceslovnou partikuli, na rozdíl od frazémů, které se vyskytují samostatně: až tak strašný to nebylo vs. Až tak!; Tak at prijidou vs. Tak at!

\subsubsection{Kumulace partikulí ve výpovědi}

Kumulace dvou a více partikulí vedle sebe, jež jsou volnými textovými kolokacemi anebo taky shluky ${ }^{8}$ dvou a více slov, též poukazují na jistý projev preferencí při kombinaci partikulí.

Řetězení partikulí - od dvou do pěti - se vyskytlo zhruba ve $12 \%$ materiálu. Nejpočetnější skupinou je řetězec dvou partikulí - celkem se v PMK vyskytlo 6948 takovýchto kontextů, což je 9,4 \% všech výskytů partikulí. Mluvčí při

\footnotetext{
8 Za shluky považujeme kombinace s nízkou frekvencí, tj. málo předvídatelné opakování kombinace.
} 
hledání lepší formulace, anebo při pokusu lépe uspořádat své myšlenky, někdy i nevědomky vysloví v pořadí další partikule, jež zpravidla netvoří žádný souvislý celek či pevnou asociativní kombinaci.

Partikule vyskytující se na první, anebo druhé pozici, jsou v zásadě stejné, liší se pouze svou frekvencí na dané pozici. Na první pozici je výrazně nejčastěǰsí partikule no (má téměř $10 \mathrm{x}$ vyšší frekvenci než na 2. pozici), po ní tak (zhruba $3 \mathrm{x}$ vyšší než na 2. pozici). Na druhé pozici nejfrekventovanější partikule jako má ale jen $2 \mathrm{x}$ vyšší frekvenci než jako na 1. pozici. Partikule vyskytující se těsně za sebou můžeme tedy rozčlenit do tří skupin:

1. partikule častěji se vyskytující na 1. pozici: no, tak, teda, ale, už, nó, jo, zase, takže, ovšem;

2. partikule častěji se vyskytující na 2. pozici: jako, a, i, taky, zase, eštěe, samožrejmě, vůbec, určitě, že, rozhodně, dyt', stejně, uplně, jaksi, totiž, jakoby, zkrátka;

3. partikule vyskytující se na obou pozicích víceméně stejně: to, prostě, asi, třeba, už, vlastně, vono, skutečně, aspoň, zrovna, myslim, koneckonci̊, zrejmě.

Na první pozici se přirozeně vyskytují partikule, jež běžně mají iniciálovou pozici i v př́ípadě, že se nekumulují. Na druhé pozici kromě nejfrekventovanějších partikulí jako, a, teda a prostě (nejfrekventovanější kombinace: no a, no ale, tak jako, teda jako, to jako, teda vopravdu, a ted', a tak) najdeme mnohem víc modálních, intenzifikačních a expresivních partikulí než na pozici první, což je zcela pochopitelné: po partikulích, jež mají výrazně počáteční pozici (no, tak) mluvčí použitím druhé partikule více specifikuje svůj postoj k vyřčenému (platí to i pro kumulační trichotomii: no a eště /potom /právě /tak /taky /takže /teda /tedka / / určitě /vlastně /vís /vưbec; no ale dyt' /jinak /právě /rozhodně /zas apod.).

Pokusíme se vystopovat nejtypičtější další preferenční kombinace nejfrekventovanějších partikulí na 1. pozici:

no - prostě (45) / asi (38) / určitě (32) / dyte / vono (24) / samožrejmě (14) / rozhodně / možná (13); tak - asi (58) / prostě (57) / samozřejmě (28) / určitě (18) / přece / vono (12) / rozhodně (10) / možná (8); a - dyt (13) / vono (12) / prostě (9) / samozřejmě (6) / asi (4); jako - prostě (32) / asi (18) / vopravdu (15) / samozřejmě (9) / určitě (7) / rozhodně / možná (4); teda - vopravdu (32) / asi / samozřejmě (17) / skutečně (8) / prostě (7) / rozhodně (5); ale - dyt' (11) / prostě (10) / vono (9) / asi (8) / rozhodně / vopravdu / přece (5) / samožrejmě (4) / určitě (3).

Ze všech faktuálních partikulí se jako nejuniverzálnější jeví partikule asi: na obou pozicích má přibližně stejnou frekvenci. Nejen že jsou nejčastější kombinace no / tak / jako / teda + asi, ale také kombinace dvou faktuálních/ faktuálně-intenzifikačních partikulí samozřejmě / vopravdu / určitě / možná / / rozhodně + asi není výjimkou, což ovšem platí i obráceně, je-li asi na první 
pozici: asi + pravděpodobně / určitě / zřejmě / vopravdu. V této významové diskrepanci je zřejmě obsažena nejistota mluvčího.

Partikule s nejvyšší restrikcí kombinací jsou prece, $d y t$ a vono. Nejčastějšími kombinacemi jsou tak / ale / a + přece, a / ale + dyt’a no / tak / a / ale + vono. Celá řada kombinací se zde ale nevyskytla: např. *jako / teda / asi / třeba / prostě / i / vlastně + prece, nebo ${ }^{\star}$ tak / jako / teda / to / asi / prostě / třeba / už / taky / $i+d y t ;{ }^{*}$ to / prostě / třeba / už / taky / i / eště / zase / vůbec / spíš / samozřejmě / snad + vono. Je to nejspíš proto, že u těchto výrazů jde o velmi silnou expresivitu, kterou nelze dále modifikovat, na těchto slovech je také velmi často důraz, a tak mají mnohem silnější první pozici (prece a $d y t$ ), u vono jsou obě pozice vyrovnané. Je-li $d y t$ na začátku dvojice, je poměrně častá kombinace $d y t^{\prime}+$ vono / přece:

dyt’ přece podmínkou je filozofická fakulta, ne?; dyt̉ přece škola není vod toho, aby studenty něčemu naučila, ale aby zaměstnala profesory; dyṫ vono už je jí taky dost apod.

Při mapování kumulací partikulí jsme vystopovali řadu dalších výrazů, jež by vzhledem k svému vysokému indexu opakování v podobných kontextech a poměrně vyhraněnému významu měly být též označeny za ustálené čili systémové víceslovné jednotky: např. tak jako, tak asi, asi tak, to teda, ba př́mo, eště navíc, zase naopak, takže vlastně, vübec ne, ani ne, potom / pak eště, ty jo. První výraz pro svou vysokou frekvenci a zcela vyhraněnou funkci ve výpovědi (váhavost, nejistota: např. toho manžela jsem tak jako milovala) v porovnání s víceslovným spojovacím adverbiem (město je většinou větší, lidi se neznaj tak jako na vesnici). $\mathrm{O}$ tom, že slůvko $b a$ vytvárí ustálené kolokace $s$ dalšími slovy svědčí též fakt, že ve FSMČ máme doloženy frazémy ba naopak a ba ne.

Téměř všechny kolokáty partikulí jako, teda a prostě, jsou-li tyto partikule na prvním místě řetězce, mají jen jeden výskyt - tím, že tyto partikule s dalšími slovy nevytvářejí žádnou pevnější vazbu, se jen potvrzuje jejich převážně výplňková funkce.

Vícenásobné kumulace (řetězení čtyř a pěti partikulí za sebou) jsou poměrně ř́dkým jevem. Více než řazení jednotlivých partikulí za sebou a jejich kombinace je zde zajímavé sledovat způsob strukturace promluvy, což nesouvisí prímo s tématem tohoto článku. Nicméně uved’me několik rysů typických pro takováto řetězení, k nimž jsme dospěli po analýze širších kontextů (zhruba 100 slov, čili 50 před a 50 po KWIC - key word in context). Vícenásobné kumulace v monologu provázejí: 1. různé fáze promluvy - začátek promluvy (no), přidání dalších příkladů (eště, navíc, potom, pak, třeba), či návrat $\mathrm{k}$ tématu s pokusem o vyvození závěru (ale, jinak); 2. kladení většího důrazu na část promluvy: ale vo tom štěsti sem mluvil ve smyslu, co může čověk sám ovlivnit. a úspěšnost, tak to je <právě možná právě zase> $v$ tom - všechny užité partikule svým způsobem zde více či méně zdůrazňují a dokreslují vyřčené tvrzení: právě - intenzifikace, možná - ubrání intenzity (zaváhání), 
právě - opakování intenzifikace jako druhý pokus o ujištění se, zase - vymezení se k předchozímu sdělení (tvrzení); 3. začátek repliky druhého mluvčího v dialogu: řetězec partikulí uvádí bud’ souhlasnou, anebo odmítavou reakci ( jo vlastně dyt'von, no dyt to prece; tak to teda rozhodně - ne), která vyplývá z rychlého zhodnocení repliky prvního mluvčího. Vyslovení více slov za sebou umožňuje recipientovi ještě chvilku zvážit, do jaké míry bude s produktorem souhlasit. Řetězcem partikulí druhý mluvčí taky rozvádí téma ( jo a to eště), či uvádí nové téma (jo ale jinak mimochodem), což souvisí vlastně s již zmíněnými fázemi promluvy; 4. celkové nadužívání partikulí v promluvě. Uved'me jednu ukázku, v níž se nevyskytuje nadužívání explikativ (no, jako, teda, prostě), jimiž idiolekt mluvčích vypomáhajících se partikulemi zpravidla oplývá, díky čemuž tento projev působí poněkud kultivovaněji ${ }^{9}$. Přesto je $\mathrm{v}$ něm $\mathrm{v}$ průměru každým pátým slovem partikule:

(83 slov - 18 partikulí), <promluva ZVAF ${ }^{10}$, č. m. 260>

prostě to, nemám takový ambice, ale každopádně mně stačilo loni, a ty to dobře višs, když sem nastoupila vlasně do zaměstnání, že jo, že to byl pro mě šílenej šok, jó, starat se teda tady vo, vo dvouapưlletýho synka a <potom eště teda že jo $>$, chodit tak ňák slušně vypadající do školy, něco tam slušně vodvykládat, slušně se vrátit domu, a zase se teda postarat o tu rodinu, a to sme z toho teda eliminovali ten veřejnej život, že bych se někde angažovala prostě

\subsection{Místo výskytu partikulí}

Již zmíněný Kódovník PMK (viz Příloha) na 4. pozici uvádí valenci partikulí. Rozlišovali jsme 4 pozice, na nichž se partikule můžou vyskytnout:

1. počáteční; 2. koncovou; 3. jinou (většinou jde o pozici vyskytující se na jiném místě než na začátku či na konci věty anebo vážící se se slovem stojícím jinde než na začátku či na konci věty; její pozice je často, i když ne vždy, uprostřed promluvy); 4. tzv. pozici bližze neurčenou (tato kategorie v celém Kódovníku PMK byla ponechána pro př́pady, kdy rozhodování na základě kritérií, které nabízí kódovník, nemůže být jednoznačné ${ }^{11}$ ).

Počáteční, koncová a jiná pozice se dále člení na kombinace (valenci) partikulí s větou - adpropoziční (v kódovníku jsou kombinace partikulí s propozicí

9 Nesmíme zapomínat, že jde o běžně mluvený projev, jenž se bez hojného výskytu partikulí neobejde. $Z$ hlediska plynulosti, srozumitelnosti a celkového vyznění zde uvedené promluvy však nelze říct, že jde o nadužívání partikulí, které je často příznačné pro nekultivované projevy.

10 Z-žena, V-nad 35 let, A-vysokoškolské vzdělání, F-formální nahrávka, tj. monolog

$11 \mathrm{~V}$ prŕpadě partikulí jde o jejich výskyt $\mathrm{v}$ nedokončených větách, $\mathrm{v}$ kontextu narušené větné struktury, elize, různých vybočení, digrese, kratších či delších odmlk, tápání při hledání lepší formulace a adekvátnějšího uchopení myšlenky. Partikule při takovýchto sděleních nemá tedy svou většinově běžnou funkci, respektive nevyskytuje se v běžné pozici, a tudíž nezapadá do žádného kontextu. Mluvčí o ni spíše zavadí, přičemž se tok jeho myšlenek ubírá jiným směrem. 
označeny čísly 1, 2 a 3), anebo se slovem - adlexémové (v kódovníku čísla 4, 5 a 6). Takto jsme dohromady získali 7 možností, přičemž 7 . možností je zmíněná poslední pozice blíže neurčená. Tato pozice byla také nejméně zastoupena: takto bylo z celkového materiálu označeno pouze $2,21 \%$ pozic.

Naplnění jednotlivých pozic na základě kritérií analýzy materiálu PMK ukazují níže uvedené grafy $1-3$. Graf 1 znázorňuje poměr partikulí pojících se s větou, či se slovem; Graf 2 pozici partikulí v promluvě a konečně Graf 3 procentuální naplnění kombinací všech pozic (počáteční, koncová, jiná pozice adpropoziční nebo adlexémová a pozice blíže neurčená):

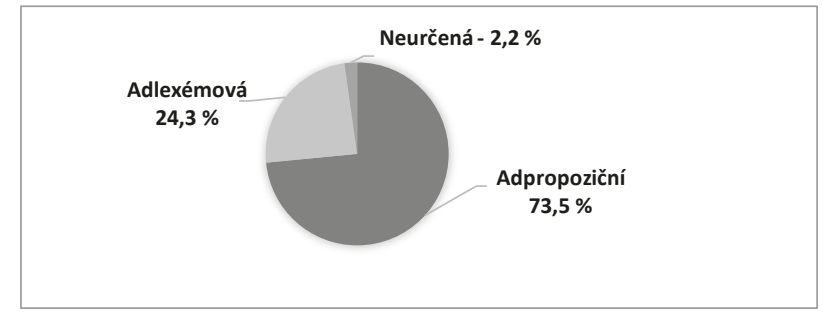

Graf 1. Poměr adpropozičních a adlexémových partikulí v PMK

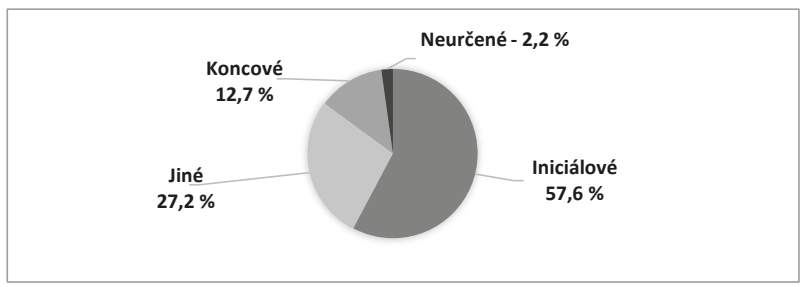

Graf 2. Místo výskytu partikulí v promluvě v PMK

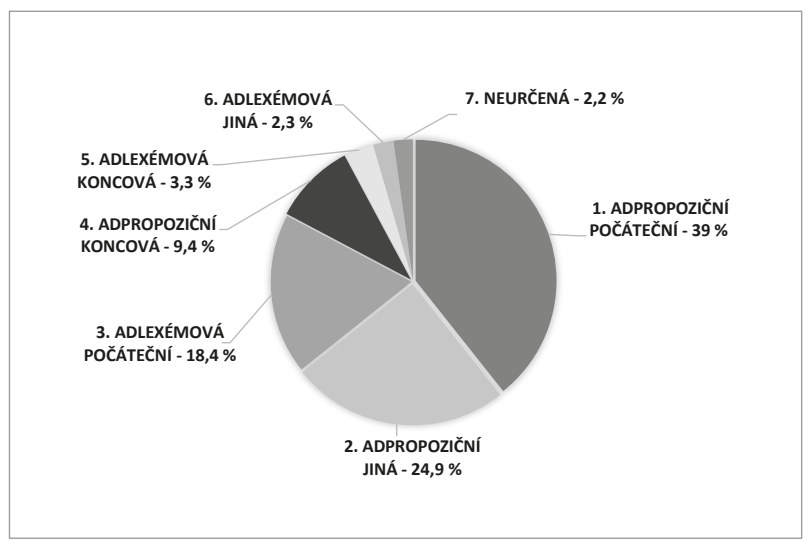

Graf 3. Celková frekvence tvarů partikulí podle místa výskytu a valence v PMK 
$Z$ důkladné analýzy výskytu partikulí v promluvě v materiálu PMK vyplynulo:

- partikule se tř̀ikrát častěji kombinují s větou než se slovem; adpropoziční počáteční pozice je dvakrát častější než adlexémová počáteční, adpropoziční koncová je až třikrát častější než adlexémová koncová;

- nejsilnější pozicí, 57,6\%, je pozice počáteční (nejfrekventovanější: no, tak, a, to, jako, teda, prostě, no tak, ale, třeba);

- na koncovou pozici připadá zhruba 13 \% výskytů (nejfrekventovanější: že jo, jo, no, vid', teda, nó, víš, ne, taky, jó);

- zhruba třetina partikulí se vyskytla uprostřed promluvy (nejfrekventovanější: teda, jako, prostě, asi, taky, třeba, že jo, zase, tak, vlastně);

- nejvýraznější adlexémové partikule jsou dokonce $i, a z ̌, i, z v l a ́ s ̌ t$, próímo, zejména, doslova a třeba $i$; všechny další adlexémové partikule se v mnohem větší míře kombinují též i s větou.

Pokud jde o tvary partikulí, z materiálu PMK vyplynulo, že jsou téměř všechny partikule polyvalenční, resp. mohou se vyskytnout na jakémkoli místě v promluvě, přičemž se pojí bud's větou, anebo se slovem. Odlišné jsou pouze frekvence tvarů na jednotlivých pozicích a zde jednotlivé partikule vykazují zcela jasné preference. Nicméně mluvený jazyk je natolik mnohotvárný a nepředvídatelný, že s jistotou můžeme říct, že zde platí pouze tři pravidla:

- pokud je silná počáteční pozice, koncová se vyskytuje jen sporadicky a obráceně;

- ustálené víceslovné kombinace můžeme čekat jen u adpropozičních partikulí;

- adlexémové partikule vznikají ad hoc v kontextu, jsou tedy nepředvídatelné, jejich kolokace nejsou pevné, a tudíž nemají vysokou frekvenci (napr. všechny kolokáty adlexémové počáteční partikule teda mají frekvenci 1).

Následující tabulka (Tabulka 2) znázorní tyto poznatky na př́íkladu několika vybraných partikulí (faktuální a faktuálně-intenzifikační třída; nejobsazenější pozice jsou v tabulce zvýrazněny):

\begin{tabular}{|l|c|c|c|c|c|c|c|c|}
\hline \multicolumn{2}{|c|}{ lemmata } & \multicolumn{3}{|c|}{$\begin{array}{c}\text { Adpropoziční } \\
\text { valence }\end{array}$} & \multicolumn{3}{c|}{ Adlexémová valence } & \multirow{2}{*}{$\begin{array}{c}\text { neurčená } \\
\%\end{array}$} \\
\cline { 1 - 8 } faktuálnín & intenzifikačnín & $\begin{array}{c}\text { poč. } \\
\%\end{array}$ & $\begin{array}{c}\text { kon. } \\
\%\end{array}$ & $\begin{array}{c}\text { jiná } \\
\%\end{array}$ & $\begin{array}{c}\text { poč. } \\
\%\end{array}$ & $\begin{array}{c}\text { kon. } \\
\%\end{array}$ & $\begin{array}{c}\text { jiná } \\
\%\end{array}$ & \\
\hline teda & 20,35 & 3,65 & $\mathbf{4 0 , 0 7}$ & 18,71 & 5,51 & 2,08 & 2,59 \\
\hline jako & 25,27 & 1,71 & 34,44 & 25,77 & 4,54 & 3,75 & 4,5 \\
\hline tak & $\mathbf{7 6 , 8 6}$ & 0,5 & 11,34 & 7,62 & 0,09 & 0,95 & 2,63 \\
\hline že jo & 0,41 & $\mathbf{6 8 , 6 1}$ & 23,43 & 0,25 & 6,1 & 0,83 & 0,33 \\
\hline
\end{tabular}




\begin{tabular}{|c|c|c|c|c|c|c|c|c|}
\hline \multicolumn{2}{|c|}{ lemmata } & \multicolumn{3}{|c|}{$\begin{array}{l}\text { Adpropoziční } \\
\text { valence }\end{array}$} & \multicolumn{3}{|c|}{ Adlexémová valence } & \multirow{2}{*}{$\begin{array}{c}\text { neurčená } \\
\%\end{array}$} \\
\hline faktuální & intenzifikační & $\begin{array}{c}\text { poč. } \\
\%\end{array}$ & $\begin{array}{c}\text { kon. } \\
\%\end{array}$ & $\begin{array}{c}\text { jiná } \\
\%\end{array}$ & $\begin{array}{c}\text { poč. } \\
\%\end{array}$ & $\begin{array}{c}\text { kon. } \\
\%\end{array}$ & $\begin{array}{c}\text { jiná } \\
\%\end{array}$ & \\
\hline \multicolumn{2}{|l|}{ asi } & 19,94 & 2,26 & 36,95 & 32,14 & 2,67 & 2,76 & 2,93 \\
\hline \multicolumn{2}{|l|}{ jo } & 4,33 & 60,88 & 18,16 & 1,23 & 14,24 & 0,3 & 0,82 \\
\hline \multicolumn{2}{|l|}{ vlas(t)ně } & 26,27 & 2,62 & 49,1 & 14,52 & 3,18 & 1,38 & 2,9 \\
\hline \multicolumn{2}{|l|}{ ale } & 75,00 & 2,00 & 17,5 & 3,66 & 0,5 & 0,00 & 1,33 \\
\hline \multicolumn{2}{|l|}{ zase } & 34,13 & 2,06 & 44,65 & 13,1 & 1,03 & 1,55 & 3,44 \\
\hline \multicolumn{2}{|l|}{ taky } & 19,45 & 4,32 & 31,17 & 27,2 & 8,46 & 4,32 & 5,04 \\
\hline \multicolumn{2}{|l|}{ v/opravdu } & 23,48 & 3,86 & 34 & 30,9 & 1,93 & 2,2 & 3,59 \\
\hline \multicolumn{2}{|l|}{ i } & 4,72 & 0,00 & 2,15 & 80,5 & 1,06 & 9,04 & 1,88 \\
\hline \multicolumn{2}{|l|}{ eště } & 22,22 & 2,5 & 20,12 & 39,2 & 4,82 & 7,75 & 3,35 \\
\hline \multicolumn{2}{|l|}{ už } & 25,94 & 0,66 & 36,3 & 23,94 & 1,99 & 9,75 & 1,33 \\
\hline \multicolumn{2}{|l|}{ vůbec } & 16,19 & 4,31 & 40,2 & 28,00 & 4,96 & 4,96 & 1,51 \\
\hline \multicolumn{2}{|l|}{$\mathrm{až}$} & 5,22 & 0,00 & 0,65 & 84,5 & 1,3 & 5,2 & 2,6 \\
\hline \multicolumn{2}{|l|}{ aspoň } & 32,3 & 2,2 & 8,00 & 49,3 & 0,73 & 6,6 & 0,73 \\
\hline \multicolumn{2}{|l|}{ navíc } & 83,4 & 0,00 & 11,1 & 0,00 & 5,5 & 0,00 & 0,00 \\
\hline \multicolumn{2}{|l|}{ zejména } & 22,22 & 0,00 & 11,11 & 66,66 & 11,11 & 0,00 & 0,00 \\
\hline \multicolumn{2}{|l|}{ zvláště } & 21,5 & 0,00 & 7,1 & 64,3 & 7,1 & 0,00 & 0,00 \\
\hline \multicolumn{2}{|l|}{ kór } & 30,7 & 0,00 & 0,00 & 69,3 & 0,00 & 0,00 & 0,00 \\
\hline \multicolumn{2}{|l|}{ dokonce i } & 0,00 & 0,00 & 0,00 & 90,9 & 0,00 & 9,1 & 0,00 \\
\hline
\end{tabular}

Tabulka 2. Poměry faktuálních a intenzifikačních partikulí s frekvencí > 10 na jednotlivých pozicích

Pro lepší názornost uvedeme několik př́ikladů kódování velmi četné partikule teda:

- ADPROZIČNÍ POČÁTEČNÍ (1): vono teda taky záleži na tom

- ADPROZIČNÍ KONCOVÁ (2): tak mě to začalo bavit teda

- ADPROPOZIČNÍ JINÁ (3): prostě ty ženský sou teda stahaný a vyř́zený

- ADLEXÉMOVÁ POČÁTEČNí (4): vidíte klacky, třinác, čtrnác let, nad nima stojí matka, teda žena s dvěma taškama, ani je nenapadne se zvednout

- ADLEXÉMOVÁ KONCOVÁ (5): ta mládež teda by se vioči těm starším a tomu okolí méla chovat slušně

- ADLEXÉMOVÁ JINÁ (6): je to i známý, že jo, nejen teda z pohledů těch učitelü, ale vi̊bec teda těch lidí, který se stím zabejvaj 
- NEURČENÁ (7): dycky špatný př́pad pưsobí lepší než ten dobrej a dycky každej spiš teda, zvláště u mladejch lidí, že jo, víc je sváděj špatný př́klady než dobrý, já myslim

\section{Bezprostřední okolí partikulí}

V bezprostředním okolí partikulí jak zleva, tak i zprava se kromě interpunkčních znamének - čárky, tečky, dvě až tři tečky (v přepisu značící kratší či delší odmlku mluvč́ho) a otazníku nejčastěji vyskytují různá další synsémantika: spojky, další partikule, reflexivní částice, pomocná verba, adverbium tam a osobní či ukazovací zájmena, především já a ty. Vysoké procento interpunkčních znamének hlavně před partikulemi (2,5krát více než zprava) svědčí o jejich výrazně nejčastější iniciálové pozici ve výpovědi. Dvakrát vyšší výskyt dvou a tř́ teček zleva zase vypovídá o mnohem pravděpodobnějším výskytu partikule v toku vyprávění po jakémkoli zaváhání či hledání správného slova a lepší formulace.

V níže uvedené tabulce (Tabulka 3) je zobrazeno prvních 20 nejčetnějších pozic v levém a pravém okolí partikulí:

\begin{tabular}{|l|l|l|l|}
\hline \multicolumn{2}{|c|}{ Levé okolí } & \multicolumn{2}{c|}{ Pravé okolí } \\
\hline, & 18298 &, & 7601 \\
\hline. & 6773 & to & 2970 \\
\hline to & 3004 & jo & 2622 \\
\hline a & 2527 &. & 2354 \\
\hline že & 2016 & tak & 2157 \\
\hline je & 1748 & a & 1628 \\
\hline.. & 1624 & je & 1329 \\
\hline tak & 1407 & se & 1304 \\
\hline no & 1406 & v & 1275 \\
\hline ale & 1387 & .. & 1158 \\
\hline se & 1019 & jako & 1113 \\
\hline$?$ & 987 & na & 1098 \\
\hline$\ldots$ & 604 & já & 1083 \\
\hline tam & 597 & si & 898 \\
\hline jako & 556 & ty & 740 \\
\hline si & 504 & sem & 693 \\
\hline teda & 470 & že & 619 \\
\hline já & 424 & ? & 610 \\
\hline
\end{tabular}




\begin{tabular}{|l|l|l|l|}
\hline \multicolumn{2}{|c|}{ Levé okolí } & \multicolumn{2}{c|}{ Pravé okolí } \\
\hline sem & 420 & tam & 507 \\
\hline nebo & 396 & ale & 488 \\
\hline
\end{tabular}

Tabulka 3. Frekvenční seznam prvních 20 levých a pravých pozic v bezprostředním okolí partikulí

Mezi první dvacítkou levých a pravých doplnění pouze čtyři výrazy nenajdeme na opačné straně (v tabulce jsou tato slova zvýrazněna): zprava se nevyskytují no, tři tečky (dlouhá odmlka), teda a nebo, kdežto zleva nenajdeme jo, prepozice $v, n a$ a ukazovací a osobní zájmeno ty.

Porovnáme-li stejné výrazy s nejvýše odlišnou četností zleva a zprava, jsou to:

\begin{tabular}{|l|l|l|l|l|l|}
\hline \multicolumn{3}{|c|}{ Výrazně vyšší levé okolí } & \multicolumn{3}{c|}{ Výrazně vyšší pravé okolí } \\
\hline zleva & word & zprava & zleva & word & zprava \\
\hline 86 & tom & 3 & 10 & v & 1275 \\
\hline 159 & který & 12 & 19 & na & 1098 \\
\hline 63 & což & 5 & 218 & jo & 2622 \\
\hline
\end{tabular}

Tabulka 4. Nejvýraznější rozdíly v distribuci levého a pravého doplnění partikulí

Prepozice před partikulí je poměrně vzácná - pouze prepozice před partikulemi zdůrazňujícími míru naplnění, např. úplně, naprosto, čistě, př́liš apod. ve výrazech na uplně / naprosto jiné úrovni, v uplně / naprosto jiné situaci, v uplně / naprosto dezolátním stavu, $\boldsymbol{v}$ naprosto liberálních pomèrech, $\boldsymbol{v}$ čistě křstanským (kroužku) - vnímáme jako koherentní verbální projev, a to proto, že s adjektivem tvoří pevnou kolokaci (uplně jiný, naprosto dezolátní, čistě křestanský). Dalším koherentním příkladem je berou drogy $\boldsymbol{v}$ čím dál větší míre. Většina dalších příkladů (kromě partikulí teda a jako, které snad lze vložit kamkoli - srov. poslední dva př́íklady) je často poznamenaná narušením aktuálního členění, což je nejspíš způsobeno hledáním lepšího, vhodnějšího příkladu, anebo náhlým zaváháním mluvčího $-\mathrm{v}$ těchto př́kladech vždy jde o adlexémovou valenci:

- což si myslim, že by $\mathbf{v}$ třeba takovejch institucích pohyblivou, nebo jak tomu říkaj, pracovní dobu pohyblivou...

- a neni mezi nima rozdíl $\mathbf{v}$ jaksi v odbornosti, sou kolem pětatřriceti

- nedávno slyšel, že někde $\mathbf{v}$ snad $v$ Austrálii se přemnožili špačci

- změny, kerý sem zaznamenala na konkrétně... budově naší, tak sou to

- to je prostě zločin na... na vủbec morálnim profilu toho člověka todlencto

- /drogy/...těžko říct, reakce na asi současnou situaci, protože dříve si myslim, že to nebylo $\mathrm{v}$ takové míre

- tenkrát za první republiky bylo na jako daleko vy̌ším stupni 
- rozdělila bych to vzdělání na teda takové nutné, základní, které by snad eště šlo zredukovat

Velmi silnou pozici před partikulemi má ovšem předložkovýlokál: tvar tom (viz Tabulka 4) se před partikulí vyskytuje až 30krát častěji než za ní. Jde o př́klady typu

sou na tom asi hůr̆, sem vo tom ňák slyšel, nevidim $\mathbf{v}$ tom ani tak chybu velkou přímo, to na tom vůbec nezávisí, věkové kategorie se $\mathbf{v}$ tom samozřejmě liší, finančně sou na tom asi ty chlapi lepší, hraje $\mathbf{v}$ tom určitě roli ekonomická stránka rodiny, na tom teda ted'ko pracuju dost intenzivně, na tom prakticky nezáleželo, ženy sou na tom kupř́ikladu platově hưř atd.

Na těchto příkladech je též zřejmé, nakolik je partikule flexibilní.

Vysoký výskyt tvaru tom mě inspiroval k tomu podívat se blíže i na výskyt dalších pádů zájmena ten $\mathrm{v}$ bezprostředním okolí partikulí.

Např́klad tvar tomu se před partikulí vyskytuje pouze 3krát častěji než po ní. Před partikulí tvar tomu těsně souvisí se syntaktickou stavbou věty a často se též vyskytuje po prepozici:

- nevěřili sme tomu vid’?; uplně sem tomu ani nechtěla věřit; své děti učím tomu teda; člověk tomu až jako nevěří; já tomu jako docela rozumím; co by tomu teda mohlo zabránit; mysim, že z Cimrmana tomu ještě leccos chybí;

- určitě přispělo $\mathbf{k}$ tomu taky; to snad patří $\mathbf{k}$ tomu, né?; nemưže v účetnictví se k tomu vůbec dostat; nemá $\mathbf{k}$ tomu třeba ani žádný předpoklady; no to $\mathbf{k}$ tomu zase asi maj ty ženský přece jenom blíž; je to strašnej nesmysl a proti tomu teda bojuju; co bych $\mathbf{k}$ tomu eště řekla.

Takovýchto příkladů v obráceném pořadí (PART+tomu) je tedy třikrát méně. Nejčastější kombinací je tak tomu, teda tomu:

- tak tomu nechtěla vůbec věřit; tak tomu bylo dycky tak; žena musí rozhodnout, jestli teda tomu bude věnovat ten čas;

- já sem prej tomu pánovi strašně děkovala; prostě tomu chybí... tomu chybí...; at' chce sebevíc, tak stejně tomu nemůže dát prostě to maximum.

Na rozdíl od dativu a lokálu, instrumentálový tvar tim /tím se ovšem v PMK vyskytl dvakrát častěji po partikuli. Téměř všechny výskyty jsou stejné:

je to (asi, spíš, taky, teda, třeba, vlastně, zase) tim, že...; je to dáno (asi, právě, hlavně,

i) tím, že...; tak tím je to horší apod.

Z četných příkladů je zřejmé, že tvar tim / tím před partikulí mnohem více souvisí s predikátovou valencí a často se vyskytuje též po prepozici:

- u nás to souvisí ale $\mathbf{s}$ tim spíš bych řekl, kdo je majitel budovy

- nemůžeš se nad tim dost dobře zamyslet ... jó

- setkáváme se $\mathbf{s}$ tim celkem dost často 
- a budem $\mathbf{s}$ tim asi muset něco dělat

- prosim tě, to, nad tim vubec nehořekuj, prosim tě.

- spíš se nad tim jako někdy usměju

- to s tim ale nemůžu srovnávat

- tu rodinnou výchovu tim teda nenahradíme

- s tim ani nepočítaly

- s tím absolutně / rozhodně / taky nesouhlasim

- s tím bohužel nic nenadělám

- tím vůbec nic nespravís

- no a tak se mezi tim stejně plácáme všichni

- Kučera ňák asi je s tim taky smířenej, takže prostě ... jako...

Přestože je rozsah materiálu poněkud limitující, z výše uvedených př́ikladů z PMK se nám nabízí zajímavý závěr: předložková vazba před partikulemi mnohem těsněji souvisí se syntakticko-morfologickou strukturou věty, tj. slovesnou valencí, přičemž se bezprostředně před partikulí vyskytují ukazovací zájmena odkazující na pád této valence. Prepozice těsně po partikulí, jejíž výskyt je mnohočetně vyšší než před partikulí, je spíše volným doplněním, adverbiálem, součástí frazémů či víceslovných prepozic:

- až do neprŕíčetnosti, prostě do krajnosti, taky do určitý míry;

- docela na úrovni, až na konci, asi na štyri měsíce, ale na druhou stranu, jako na úkor rodiny, prostě na každým rohu, samozřejmě na prvním místě;

- prostě po čase, teda po tý technický stránce, teda po stránce vzdělání;

- to $\mathbf{v}$ žádným př́padě, třeba $\mathbf{v}$ současné době, třeba $\mathbf{v}$ tý politice, třeba $\mathbf{v}$ tech $\mathrm{Bu}$ dějovicích, vlasně $\mathbf{v}$ podstatě, vlastně $\mathbf{v}$ průběhu tejdne, zř̌ejmě $\mathbf{v}$ dnešní době, zvláště v tom prostředí;

- prostě vod př́rody, prostě vod začátku, teda vod té doby;

- tak / teda / třeba u nás;

- tř̌eba z mýho okolí, uplně z ničeho nic, zase $\mathbf{z}$ vlasní zkušenosti;

- jako za nás, jako za prvý, prostě za slušnej peníz, teda za žádnou cenu.

\section{Závěr}

V článku jsme nastínili způsob určování valence partikulí, jenž byl uplatněn při ručním značkování prvního mluveného korpusu češtiny, Pražského mluveného korpusu. Valence partikulí souvisí s místem jejich výskytů v promluvě a jejich spojitostí s celou propozicí, anebo s jednotlivými slovy ve výpovědi. Rozlišili jsme systémové víceslovné partikule vznikající na základě vnitřní syntagmatiky jejích členů od náhodných textových kumulací vykazujících též jisté preferenční kombinatorické možnosti. Výsledky analýzy manuálně zpracovaných autentických dat $\mathrm{v}$ rozsáhlých kontextech by měly přinést další hlubší poznatky týkající se uspořádání a strukturování mluveného projevu, místa výskytu a funkce partikulí, 
jež se na něm podílejí velkou měrou. Měly by též vést $k$ lepšímu rozpoznání partikulí při jejich automatickém značkování v rozsáhlejších mluvených korpusech a v neposlední řadě mají význam i při výuce češtiny pro cizince.

\section{Příloha - Zpracování partikulí podle Kódovníku PMK}

\section{1. pozice - slovní druh, tj. částice (partikule)}

\section{2. pozice - druh:}

1) vlastní, nehomonymní: at', asi, prej

2) homonymní s adverbiem: jistě, klidně, stejně, dovopravdy, zvlášt, jen

3) homonymní se spojkou: však, tedy

4) jiné1 ${ }^{12}$ :

a) homonymní se substantivem nebo jeho předložkovým pádem: fakt, celkem, napríklad, dokonce

b) homonymní se zájmenem nebo jeho předložkovým pádem: což, copak, vono (von, voni), to; ovšem

c) homonymní se slovesným tvarem: myslím, prosím

d) mající formu adverbia, ale nehomonymní s adverbiem užívaným jako deadjektivní adverbiále: hlavně, vlastně

e) homonymní s citoslovcem nebo citoslovečným frazémem: vid', višs, bohužel

f) jinojazyčného původu: holt, kór

5) víceslovné: že jo, dejme tomu, no tak, nějak tak, (k)dyž tak, když už, přece jenom, hlavně že

\section{3. pozice - třída:}

1) faktuální (signalizuje nezaujatý vztah mluvčího k faktu, ke skutečnosti, popř. hodnotí pravděpodobnost): tak, jinak, jako, teda, jo; možná, asi, spíš

2) faktuálně-evaluativní (s podílem hodnocení podaného kvaziobjektivně): stejně, prakticky, dyt', čím dál tím

3) faktuálně-intenzifikační (s podílem hodnocení míry, intenzity ap.): (to) vưbec (není pravda), rozhodně (to neuznávám), (dost se vo tom píše a) zvlášt' (ve Vlastě), (todlecto) ani (neni dobrý)

4) voluntativní: at', řeknème

5) voluntativně-evaluativní (spojení subjektivního hodnocení s projevem vůle/lhostejnosti): (když člověk pomyslí) tř̌ba (na letce), klidně (by mohla), (trochu si toho mám vážit) $k d y z \check{z} u z ̌$ (je jednou mám)

12 Tato původní klasifikace, opírající se do značné míry o etymologii slov hlavně v bodech a), d) a f), anebo možnou funkci v promluvě - bod e), se v kontextu skutečného úzu partikulí v promluvě jeví poněkud jinak. V celém korpusu se řada zde uvedených výrazů v kontextu promluvy vyskytuje pouze ve funkci partikule. Mezi vlastní, nehomonymní partikule z kontextového hlediska byly zařazeny také mj. celkem, dokonce (zde bod a), hlavně, vlastně (zde bod d), vid', bohužel (zde bod e), holt, kór (zde bod f) a řada dalších. 
6) expresivně-evaluativní / intenzifikační: no tak, docela, tak ňák/nějak, a vưbec, jen (koukni)

7) emocionálně-evaluativní / intenzifikační: bohužel, vyloženě

8) faktuálně-expresivní (+ evaluativní): prostě, halt, vono (je to dost jako špatný)

9) jiné: kombinace no/nó, ale, výčtové pak (má malej plat)

\section{4. pozice - valence:}

1) adpropoziční - počáteční, tj. k celé větě - začáteční: tak (já si myslim...), vono (totiž na tom nezáleží), asi (sou rodiče mírnější, než byli)

2) adpropoziční - koncová, tj. k celé větě - koncová: (musel brzdit) prostě; ... a tak; ... (̌̌e) jo; ... nebo něco

3) adpropoziční - jiná, tj. k celé větě - jiná: (potom tam) asi (bude hrát velkou roli), (když chce) třeba (někdo ject někam do př́rody), (to se) vưbec (neví)

4) adlexémová - počáteční, tj. $\mathrm{k}$ jednotlivému výrazu - začáteční: (mají) vopravdu (větší vztah k...), třeba (celá vesnice)

5) adlexémová - koncová, tj. k jednotlivému výrazu - koncová: (takovej vlastně kolotoč) no; (a ročníkový práce) řekněme

6) adlexémová - jiná, tj. k jednotlivému výrazu - jiná (vložená do víceslovného výrazu): (bez) třeba (nápadu), (mý přítelkyně) taky (známá), (v učňovských) např́íklad (školách), (že se) ani (nemoh votočit)

7) jiná, neurčeno, nelze posoudit

\section{5. pozice - modus věty:}

1) konstatovací/oznamovací: (musel brzdit) prostě; (to já taky nevim), že jo

2) tázací: (večer ho budeš vodit ty venčit), že jo?

3) imperativní/zvolací: tak (dělej), at' (nezakládaj rodinu)

4) jiný nebo smíšený: (já snad) abych (šel zalejvat)

\section{6. pozice - styl promluvy}

1) styl základní - styl neformálních ústních projevů, tj. styl běžně mluvený: von (z toho kouká) asi (takovej průšvih), že jo

2) styl mluvený=psaný (styl mluveného projevu výrazně se blížící stylu projevů psaných): (on by se) prý (rád na to) asi (podíval), že ano

3) styl knižní: (je to divné), ba (zarážející)

4) styl vulgární: (to je) fakt (průser)

\section{Bibliografie}

Bauer, L. (1988). Introducing Linguistic Morphology. Edinburgh: Edinburgh University Press.

Čermák, F. (1990). Syntagmatika a paradigmatika českého slova. II. Morfologie a tvoření slov. Praha: Univerzita Karlova. 
Čermák, F. (1997). Jazyk a jazykověda. Praha: Pražská imaginace.

Čermák, F. (2001). Syntagmatika slovníku: typy lexikálních kolokací. In: Z. Hladká, P. Karlík (eds.), Čeština - univerzália a specifika 3 (223-232). Brno: Masarykova univerzita.

Čermák, F., Holub, J. (2005). Syntagmatika a paradigmatika českého slova: valence a kolokabilita. Praha: Karolinum.

Čermák, F. et al. (2001). Pražský mluvený korpus (PMK): přepisy nahrávek pražské mluvy $z$ 90. let 20. století. Praha: Ústav Českého národního korpusu FF UK. http://www.korpus.cz.

Čermák, F. et al. (2007). Frekvenční slovník mluvené češtiny. Praha: Nakladatelství Karolinum [FSMČ].

Čermák, F. et al. (2009). Slovník české frazeologie a idiomatiky. Výrazy neslovesné, 2. díl. Praha: Leda [SČFI].

Filipec, J., Čermák, F. (1985). Česká lexikologie. Praha: Academia.

Filipec, J., Daneš, F. (2003). Slovník spisovné češtiny pro školu a veřejnost. Praha: Academia [SSČ].

Grepl, M. (2004). Funkce částic (partikulí) ve výstavbě českých výpovědi. In: E. Rusínová (ed.), Přednášky a besedy z XXXVII. běhu LŠSS (49-56). Brno: Masarykova univerzita - Filozofická fakulta.

Karlík, P. et al. (eds.) (2017). Nový encyklopedický slovník češtiny. Praha: Nakladatelství Lidové noviny. https://www.czechency.org [NESČ].

Matthews, P.H. (1991). Morphology. Cambridge: Cambridge University Press.

Uličný, O. (1986). Částice. In: M. Komárek et al. (eds.), Mluvnice češtiny. 2, Tvarosloví (228-238). Praha: Academia [AMČ 2].

ABSTRAKT: Článek se zabývá popisem valence partikulí v mluvené češtině. Vychází z materiálu Pražského mluveného korpusu (PMK), prvního českého mluveného korpusu. Po stručném představení výchozího korpusového materiálu a hlavních výsledků šetření se soustředí na popis valence partikulí, tj. jejich schopnost vázat se na jiná slova ve větě, nebo na celou větu, což úzce souvisí s místem jejich výskytu. Dále se zaměřuje na kumulaci partikulí v promluvě, která je z pohledu syntagmatiky převážně textová a zachycuje pouze náhodně se opakující textové kombinace dvou nebo více partikulí vedle sebe, na rozdíl od systémové, jejímž výsledkem jsou víceslovné partikule. Oba procesy však ukazují na kombinatorické možnosti partikulí. Nakonec je představeno bezprostřední okolí všech partikulí, které se vyskytly v PMK. 


\title{
WALENCJA PARTYKUŁ NA PODSTAWIE DANYCH Z PRASKIEGO KORPUSU MÓWIONEGO
}

\begin{abstract}
ABSTRAKT: Artykuł dotyczy opisu walencji partykuł w języku czeskim. Oparty jest na materiale Praskiego korpusu języka mówionego (PMK), pierwszego czeskiego korpusu języka mówionego. Po krótkim wprowadzeniu wstępnego materiału korpusowego i głównych wyników badań, artykuł skupia się na opisie walencji partykuł, czyli ich zdolności wiązania się z innymi słowami w zdaniu lub z całym zdaniem, co jest ściśle związane z miejscem ich występowania. Koncentruje się również na kumulacji partykuł w mowie, która z punktu widzenia syntagmatyki jest głównie tekstowa i wychwytuje tylko przypadkowo powtarzające się tekstowe kombinacje dwóch lub więcej partykuł obok siebie, w przeciwieństwie do systemowej, wynikiem które są partykuły wielowyrazowe. Jednak oba procesy wskazują na kombinatoryczne możliwości partykuł. Na koniec przedstawiono bezpośrednie otoczenie wszystkich partykuł, które wystąpiły w PMK.
\end{abstract}

